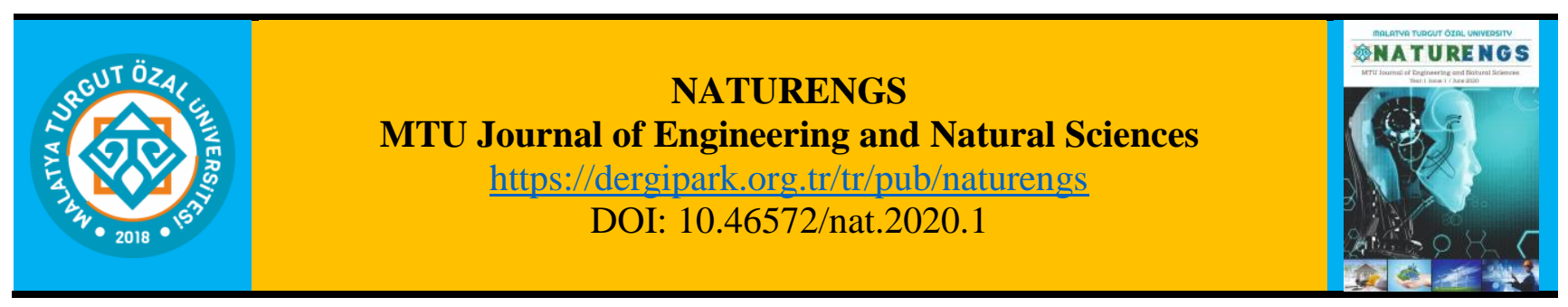

\title{
A Comparison of the Relationship Between Electricity Consumption and Gross Domestic Product According to Development Status of Countries
}

\author{
Özlem AKAY ${ }^{1^{*}}$, Esma KAHRAMAN², Ahmet Mahmut KILIÇ³ \\ ${ }^{1}$ Department of Statistics, Faculty of Science and Letters, Çukurova University, Adana, Turkey. \\ ${ }^{2,3}$ Department of Mining Engineering, Faculty of Engineering, Çukurova University, Adana, Turkey.
}

(Received: 03.02.2020; Accepted: 18.03.2020)

\begin{abstract}
Electricity is a requirement for the economic, social and cultural progress for all developed, developing and under-developed countries. This paper examines the relationships between electricity consumption and gross domestic product in 30 countries, using data for the period 1995-2014. These countries are classified according to their developmental status. Widely used tests for the panel unit root, heterogeneous panel cointegration, and panel-based error correction models were employed. The empirical results indicate that electricity consumption and economic growth appear to be cointegrated. The long-run and short-run relationships are estimated using suitable estimations. The results show that the developmental levels of countries differ in their impact on the relationship between electricity consumption and GDP.
\end{abstract}

Keywords: Electricity consumption, Developmental status, Panel data analysis, Long-run, Short-run.

\section{INTRODUCTION}

Energy is considered to be a prime agent in wealth generation and also a significant factor in economic development. The importance of energy in economic development has been recognized universally, with historical data attesting to a strong relationship between the availability of energy and economic activity [1]. In the past decades the world's energy demand and consumption have maintained a steady growth [2].

Economic growth, which is measured by gross domestic product (GDP), is a key determinant in the growth of energy demand. The world's GDP will rise by 3.0\% per year from 2015 to 2040. The fastest rates of growth are projected to be for the emerging, non-OECD regions, where combined GDP increases of $3.8 \%$ per year, driving the fast-paced growth in future energy consumption among those nations. In the OECD regions, GDP will grow at a much slower rate of $1.7 \%$ per year between 2015 and 2040, at least in part, because of slow or declining population growth in those regions [3].

*Corresponding Author: oakay@cu.edu.tr

ORCID number of authors: ${ }^{1} 0000-0002-9539-7202,{ }^{2} 0000-0002-4326-7202,{ }^{3} 0000-0002-2082-749 \mathrm{X}$ 
According to the International Energy Outlook Report, (EIA, 2017) world net electricity generation will increase by $45 \%$, rising from 23.4 trillion kilowatt-hours (kWh) in 2015 to 34.0 trillion $\mathrm{kWh}$ in 2040. Electricity is the world's fastest-growing form of end-use energy consumption, as it has been for many decades. Power systems continue to evolve from isolated, noncompetitive grids to integrated national and international markets. The strongest growth in electricity generation is projected to occur among the developing, non-OECD nations. Increases in electricity generation in non-OECD countries average $1.9 \%$ per year (Reference case (IEO 2017)) in International Energy Outlook 2017). As rising living standards increase the demand for home appliances and electronic devices, and for commercial services, including hospitals, schools, office buildings, and shopping malls increases. In the OECD nations, where infrastructures are more mature and population growth is relatively slow or declining, electric power generation will increase by an average of $1.0 \%$ per year from 2015 to 2040 in the IEO 2017 Reference case [3].

The purpose of this article was to examine the relationship between electricity consumption and gross domestic product (GDP) in 30 countries. These countries were divided into three groups: developed, developing and under-developed countries. These countries were chosen because electricity consumption and gross domestic product data in these countries are regular and complete.

Electricity consumption has been increasing day by day alongside the development of industry and population increase. This situation has led researchers to investigate the relationship between the economy and energy.

Some research has shown country-specific causality between energy consumption and economic growth and can provide insight for designing future energy policy. Bah and Azam (2017) investigated the causal relationship between electricity consumption, economic growth, financial development, and $\mathrm{CO}_{2}$ emissions for South Africa over the period 1971-2012, validating the existence of cointegration among the included variables [4]. Shahbaz and Lean (2012) showed a relationship between electricity consumption and economic growth in Pakistan, They found bi-directional Granger causality between electricity consumption and economic growth [5]. Odhiambo (2009) examined the causal relationship between electricity consumption and economic growth in South Africa by using the causality framework. Empirical results showed that there was a distinct bidirectional causality between electricity consumption and economic growth and employment in South Africa [6]. Yuan et. al (2008) tested the energy consumption and economic growth relationship for China using a neo-classical aggregate production model at both aggregated total energy and disaggregated levels of coal, oil, and electricity consumption [7]. Aqeel and Butt (2001) showed that there was a relationship between energy consumption and economic growth in Pakistan. Their paper investigated the causal relationship between energy consumption and economic growth and energy consumption and employment in Pakistan by applying techniques of co-integration and Hsiao's version of Granger causality [8].

Other researchers have shown that, by combining some countries causality studies between energy consumption and economic growth, they can provide a wider perspective for determining future energy policy. Fotis et all. (2017) showed that there was a relationship between energy demand and real Gross Domestic Product (GDP) growth and per capita Final 
Energy Consumption (FEC) in 34 countries during the period from 2005 to 2013 [9]. Oztürk et all. (2011) investigated energy consumption and GDP for 51 countries, using annual data from 1971 to 2005, by classifying countries according to national income. The populations studied were divided into three groups: low-income group, lower-middle-income group, and uppermiddle-income group [10].

They found a relationship between energy consumption and economic growth for all income groups considered in this study. Wolde-Rufael (2006) tested the causal relationship between electricity consumption per capita and real gross domestic product (GDP) per capita for 17 African countries, for the period 1971-2001. Empirical evidence showed that there was a longrunning relationship between electricity consumption per capita and real GDP per capita for only 9 countries and Granger causality for only 12 countries [11]. Soytaş and Sarı (2003) investigated the Energy consumption and GDP causality relationship in G-7 countries and emerging markets. They found bi-directional causality in Argentina, causality running from GDP to energy consumption in Italy and Korea, and from energy consumption to GDP in Turkey, France, Germany, and Japan [12]. Bozoklu and Yilancı (2003) examined the causal relationship between energy consumption and economic growth for 20 OECD countries and according to their findings, economic activity depends on energy usage and increases in energy consumption may stimulate real GDP in these countries [13].

The purpose of this article was to examine the relationship between consumption of electricity (EC) and gross domestic product (GDP) in 30 countries. These countries were divided into three groups: developed, developing and under-developed countries. These countries were chosen because the consumption of electricity and gross domestic product data in these countries are regular and complete.

\section{MATERIAL AND METHODS}

\subsection{Material}

The data set used in this paper comprises annual data, 1995-2014, for several developed, developing and under-developed countries. We divided 30 countries according to the gross domestic product classification as either developed countries, developing countries, or underdeveloped countries. The developed counties are Belgium, Austria, Portugal, Denmark, Germany, Ireland, Greece, Spain, France, Italy. The developing countries are Bulgaria, Turkey, Ukraine, Bosnia and Herzegovina, Azerbaijan, India, Moldova, Macedonia, Hungary, Croatia. The under-developed countries are Zambia, Sudan, Nepal, Senegal, Zimbabwe, Tanzania, Togo, Haiti, Mozambique, Kenya. The variables used in this study are electricity consumption [14] (EC) and Gross Domestic Product [15] (GDP). All the variables were used as natural logarithmical values in the model. Electricity consumption and GDP data are taken from the World Development Indicators database of the World for the period between 1995-2014 (Table 1) $[16]$. 
Table 1. List of Variables

\begin{tabular}{|c|c|c|c|c|}
\hline Variables & Abbreviation & Description & Period & Source \\
\hline $\begin{array}{c}\text { Electricity } \\
\text { Consumption }\end{array}$ & EC & $\begin{array}{c}\text { Electric consumption for each } \\
\text { country (kWh per capita) }\end{array}$ & Annual & WDI \\
\hline $\begin{array}{c}\text { Gross } \\
\text { Domestic } \\
\text { Product }\end{array}$ & GDP & $\begin{array}{c}\text { A measure of a country's economic } \\
\text { output that accounts for its } \\
\text { population. (current US\$) }\end{array}$ & Annual & WDI \\
\hline
\end{tabular}

\subsection{Methods}

We investigate the causal relationship between EC and GDP according to the development status of countries. Firstly, we identify the order of integration of the series using panel unit root tests. Secondly, we employ panel cointegration tests to examine the existence of a longrun relationship between the series. Finally, we estimate the long-run and short-run relationships using suitable estimations.

\subsubsection{Panel Unit Root Tests}

In panel data analysis, the panel unit root test must be taken first in order to identify the stationary properties of the relevant variables. There exist a number of methods for panel unit root tests, such as the Levin-Lin Chu (LLC) test [17], the Im-Peseran-Shin (IPS) test [18], and the Hadri test [19]. The LLC test takes into account the heterogeneity of various sections, but it has low power in small samples because of the serial correlation, which cannot be eliminated. The IPS test considers the heterogeneity among the sections and also eliminates the serial correlation, and thus has a strong ability of testing small samples, while the Hadri test is different in that the null should be reversed to be the stationary hypothesis in order to have a stronger power test.

\subsubsection{Panel Cointegration Tests}

A method for testing the null of no cointegration in dynamic panels with multiple regressors are developed by Pedroni [20].

Having established the panel unit root test, a prerequisite condition for the cointegration test is that all variables must be of order I(1). Once this condition is fulfilled, the next step is to test for the existence of a long-run cointegration of the specified variables using panel cointegration tests suggested by Pedroni [20] which comprise seven panel cointegration statistics in determining the fitness of the tests after normalizing the panel statistics with correction terms.

The tests allow for considerable heterogeneity among individual members of the panel, including heterogeneity in both the long-run cointegrating vectors as well as heterogeneity in the dynamics associated with short-run deviations from these cointegrating vectors [20].

\subsubsection{Panel Granger Causality Tests}

Granger Causality is a statistical hypothesis test that verifies whether one time series is capable of forecasting another [21]. Granger causality becomes a powerful tool to investigate the causal effect and functional relation from numerous temporal data which are easy to source today [22]. 
An underlying assumption of Granger causality is that a variable $\mathrm{X}$ Granger causes $\mathrm{Y}$ if $\mathrm{Y}$ can be better predicted using the histories of both $\mathrm{X}$ and $\mathrm{Y}$ than it can use the history of $\mathrm{Y}$ alone. Engle and Granger [23] explained that if co-integration exists between two variables in the long run, and then there must be either unidirectional or bi-directional Granger Causality between these two variables.

\section{EMPIRICAL RESULTS}

To test whether there exist any long-run and short-run relationships between electricity consumption (EC) and gross domestic product (GDP) related to the classified countries, panel unit root analysis, panel cointegration analysis, panel causality analysis, panel pooled mean group (PMG) and mean group (MG) estimates were employed in this study. The statistical software package Stata version 13.0 was used for this analysis.

Table 2 presents descriptive statistics for the log-transformed variables of interest. The second and third columns are the mean and standard deviation for each of the variables and the other columns show the correlation matrix. The correlation between electricity consumption (EC) and gross domestic product (GDP) was positive.

Table 2. Descriptive Statistics of the Log Transformed Variables

\begin{tabular}{|c|c|c|c|c|c|c|}
\hline Countries & Variable & Obs & Mean & Std. Dev. & EC & GDP \\
\hline \multirow{2}{*}{ Developed } & $\mathrm{EC}$ & 200 & 8.710 & 0.221 & 1 & \\
\hline & GDP & 200 & 10.294 & 0.424 & 0.69 & 1 \\
\hline \multirow{2}{*}{ Developing } & $\mathrm{EC}$ & 200 & 7.738 & 0.612 & 1 & \\
\hline & GDP & 200 & 7.898 & 1.067 & 0.598 & 1 \\
\hline \multirow{2}{*}{ Under-developed } & $\mathrm{EC}$ & 200 & 4.959 & 0.996 & 1 & \\
\hline & GDP & 200 & 6.258 & 0.534 & 0.3328 & 1 \\
\hline
\end{tabular}

Table 3 presents the panel unit root tests of all variables for three groups tested both for levels and for first differences. According to Levin-Lin Chu (LLC), the EC variables are stationary for developed countries while these variables include the unit root for developing and underdeveloped countries. In addition to this the GDP variables are stationary for developing countries, but these variables include the unit root for developed and under-developed countries. The Im-Peseran-Shin (IPS) test results show that the EC variables are stationary for developed countries but these variables include the unit root for developing and under-developed countries. Furthermore; the GDP variables include the unit root for all three groups. The null hypothesis of the Hadri tests is that no unit root exists in the series and the alternative hypothesis is that a unit root exists. For the three groups the unit root hypothesis is rejected when the variables EC and GDP are in level form. Therefore, the difference in the series was taken. According to the results of the unit roots test namely (LLC) and (IPS), the first difference of these variables is that they are stationary. When the first differences are taken using the Hadri tests, the GDP variables for developing countries and the EC variables for underdeveloped countries are stationary. 
Table 3. Panel unit root test results for developed status countries

\begin{tabular}{|c|c|c|c|c|c|c|c|}
\hline \multirow[b]{2}{*}{ Countries } & \multirow[b]{2}{*}{ Variables } & \multicolumn{2}{|c|}{ LLC test } & \multicolumn{2}{|c|}{ IPS test } & \multicolumn{2}{|c|}{ Hadri test } \\
\hline & & Level & $\begin{array}{c}\text { First } \\
\text { Difference }\end{array}$ & Level & $\begin{array}{c}\text { First } \\
\text { Difference }\end{array}$ & Level & $\begin{array}{c}\text { First } \\
\text { Difference }\end{array}$ \\
\hline \multirow{2}{*}{ Developed } & $\mathrm{EC}$ & $\begin{array}{c}-4.409 \\
(0.000)\end{array}$ & - & $\begin{array}{l}-2.483 \\
(0.006)\end{array}$ & - & $\begin{array}{l}25.064 \\
(0.000)\end{array}$ & $\begin{array}{l}13.478 \\
(0.000)\end{array}$ \\
\hline & GDP & $\begin{array}{l}-0.361 \\
(0.358)\end{array}$ & $\begin{array}{l}-6.072 \\
(0.000)\end{array}$ & $\begin{array}{c}2.031 \\
(0.978)\end{array}$ & $\begin{array}{l}-4.275 \\
(0.000)\end{array}$ & $\begin{array}{l}31.544 \\
(0.000)\end{array}$ & $\begin{array}{c}1.785 \\
(0.037)\end{array}$ \\
\hline \multirow{2}{*}{ Developing } & $\mathrm{EC}$ & $\begin{array}{l}-0.686 \\
(0.246)\end{array}$ & $\begin{array}{l}-8.169 \\
(0.000)\end{array}$ & $\begin{array}{c}0.715 \\
(0.763)\end{array}$ & $\begin{array}{l}-6.421 \\
(0.000)\end{array}$ & $\begin{array}{l}31.178 \\
(0.000)\end{array}$ & $\begin{array}{c}1.856 \\
(0.031)\end{array}$ \\
\hline & GDP & $\begin{array}{l}-1.799 \\
(0.036)\end{array}$ & - & $\begin{array}{c}2.181 \\
(0.985) \\
\end{array}$ & $\begin{array}{l}-5.740 \\
(0.000)\end{array}$ & $\begin{array}{l}35.217 \\
(0.000) \\
\end{array}$ & $\begin{array}{c}1.509 \\
(1.509) \\
\end{array}$ \\
\hline \multirow{2}{*}{$\begin{array}{c}\text { Under- } \\
\text { developed }\end{array}$} & $\mathrm{EC}$ & $\begin{array}{l}-0.207 \\
(0.418)\end{array}$ & $\begin{array}{l}-9.832 \\
(0.000)\end{array}$ & $\begin{array}{c}2.004 \\
(0.977)\end{array}$ & $\begin{array}{l}-10.110 \\
(0.000)\end{array}$ & $\begin{array}{l}30.040 \\
(0.000)\end{array}$ & $\begin{array}{l}0.707 \\
(0.239\end{array}$ \\
\hline & GDP & $\begin{array}{c}1.350 \\
(0.911)\end{array}$ & $\begin{array}{l}-9.376 \\
(0.000)\end{array}$ & $\begin{array}{c}4.257 \\
(1.000)\end{array}$ & $\begin{array}{l}-5.186 \\
(0.000)\end{array}$ & $\begin{array}{l}33.008 \\
(0.000)\end{array}$ & $\begin{array}{c}1.664 \\
(0.048)\end{array}$ \\
\hline
\end{tabular}

It can be seen from Table 3 that all the variables are integrated of order one, which meets the requirements of the cointegration test. In this paper the procedure proposed by Pedroni (1999) was used because it allows for the investigation of heterogeneous panels, in which heterogeneous slope coefficients, fixed effects and individual specific deterministic trends are permitted [20]. This framework provides cointegration tests for both heterogeneous and homogenous panels with seven regressors based on seven residual-based statistics. These statistics are composed of the panel cointegration tests that include four statistics and the group cointegration tests that include three statistics. Table 4 shows the results of panel co-integration tests for developed status countries.

Table 4. Results of panel co-integration tests for developed status countries

\begin{tabular}{|c|c|c|c|c|c|c|}
\hline \multirow{2}{*}{ Countries } & \multicolumn{3}{|c|}{ Panel (within dimension) } & \multicolumn{2}{c|}{ Group (between dimension) } \\
\cline { 2 - 7 } & Statistics & Value & Prob. & Statistics & Value & Prob. \\
\hline \multirow{5}{*}{ Developed } & Panel v-stat. & 2.997 & 0.998 & & & \\
& Panel rho-stat. & -0.960 & 0.168 & Group rho-stat. & 0.1346 & 0.553 \\
& Panel PP-stat. & -3.677 & 0.000 & Group PP-stat. & -3.666 & 0.000 \\
& Panel ADF-stat. & -3.562 & 0.000 & Group ADF-stat. & -3.433 & 0.000 \\
\hline \multirow{5}{*}{ Developing } & Panel v-stat. & 2.247 & 0.987 & & & \\
& Panel rho-stat. & -0.129 & 0.448 & Group rho-stat. & 1.129 & 0.870 \\
& Panel PP-stat. & -1.944 & 0.025 & Group PP-stat. & -1.222 & 0.110 \\
& Panel ADF-stat. & -2.211 & 0.013 & Group ADF-stat. & -2.793 & 0.002 \\
\hline \multirow{5}{*}{ developed } & Panel V-stat. & 0.102 & 0.540 & & & \\
& Panel rho-stat. & -0.162 & 0.435 & Group rho-stat. & 1.004 & 0.842 \\
& Panel PP-stat. & -2.29 & 0.011 & Group PP-stat. & -2.12 & 0.017 \\
& Panel ADF-stat. & -0.800 & 0.211 & Group ADF-stat. & -0.6316 & 0.263 \\
\hline
\end{tabular}

It can be seen from Table 4 that for developed countries, three panel statistics reject the null hypothesis of no cointegration and two statistics that admit that there is no cointegration between the variables, i.e. the panel v-statistic and panel rho-statistic. In the group cointegration tests, two group statistics reject the null hypothesis and one admits it. For developing countries, two panel statistics reject the null hypothesis of no cointegration and two statistics admit there is no cointegration between the variables, i.e. the panel v-statistic and panel rho-statistic. In group cointegration tests, one group statistics rejects the null hypothesis and two admit it. For 
under-developed countries, Panel PP-statistic and Group PP- statistic reject the null hypothesis of no cointegration.

Having established cointegration in the long-run by Pedroni (1999) in Table 4, we examine the direction of causality between GDP and EC in a Panel context which is based on the following regressions:

$$
\begin{aligned}
& \Delta \ln E C_{i t}=\varphi_{1 i}+\sum_{p} \varphi_{11 i p} \Delta \ln E C_{i t-p}+\sum_{p} \varphi_{12 i p} \Delta \ln G D P_{i t-p}+\psi_{1 i} E C M_{t-1} \\
& \Delta \ln G D P_{i t}=\varphi_{2 i}+\sum_{p} \varphi_{21 i p} \Delta \ln G D P_{i t-p}+\sum_{p} \varphi_{22 i p} \Delta \ln E C_{i t-p}+\psi_{2 i} E C M_{t-1}
\end{aligned}
$$

Eqs. (1) and (2) are estimated using the pooled mean group estimator (PMGE) and mean group estimator (MGE). In order to be able to choose the appropriate estimator, the Hausman test was conducted and long-run homogeneity was tested. Causality is tested based on $H_{0}: \varphi_{12 i p}=0$ and $H_{0}: \varphi_{22 i p}=0$ for all $i$ and $p$, where $p$ is the lag length for the differenced variables of the respective equations.

Eq (1) gives the estimates of the panel correction model of the variables according to development status by the mean group estimator and the pooled mean group estimator. Results of the Hausman test show that the mean group estimator for the developed (Chi-square: 3818.74 (0.000)) and developing (Chi-square: 24.65 (0.000)), according to the test results, is valid, whereas for the under-developed countries (Chi-square: $0.27(0.605)$ ) the pooled group estimator is appropriated.

Eq (2) gives the results of the Hausman test and show that, according to the test results, the mean group estimator for the developed countries (Chi-square: 78.86 (0.000)) and underdeveloped countries (Chi-square: $57.74(0.000)$ ) is valid, whereas for the developing countries (Chi-square: $1.13(0.2869)$ ) pooled group estimator is appropriated. The panel Granger causality test results are reported in Table 5.

\begin{tabular}{|c|c|c|c|c|c|c|}
\hline \multirow[b]{3}{*}{ Countries } & \multicolumn{6}{|c|}{ Source of causation (independent variable) } \\
\hline & \multirow{2}{*}{$\begin{array}{c}\text { Dependent } \\
\text { Variable }\end{array}$} & \multicolumn{2}{|c|}{ Short-run } & \multicolumn{3}{|c|}{ Long run } \\
\hline & & $\mathbf{E C}$ & GDP & EC & GDP & ECM \\
\hline \multirow[t]{2}{*}{ Developed } & $\mathrm{EC}$ & - & $-0.0367 * *$ & - & $0.038 * * *$ & $0.894 * * *$ \\
\hline & GDP & $0.893 * * *$ & - & $-1.07 * * *$ & - & $0.841 * * *$ \\
\hline \multirow{2}{*}{ Developing } & $\mathrm{EC}$ & - & $0.091 * * *$ & - & $-0.347 *$ & $0.552 * * *$ \\
\hline & GDP & -0.0265 & - & $-1.75 * * *$ & - & $0.721 * * *$ \\
\hline \multirow{2}{*}{$\begin{array}{c}\text { Under- } \\
\text { developed }\end{array}$} & EC & & $0.246 * * *$ & & $0.156 * * *$ & $0.614 * * *$ \\
\hline & GDP & $0.313^{*}$ & - & $-0.428 *$ & - & $0.834 * * *$ \\
\hline
\end{tabular}

Table 5. Causality test results

*and $* * *$ represent significance at $10 \%$ and $1 \%$, respectively.

According to the Granger causality test results, there is a long-run Granger causality running from GDP to EC for the three groups of countries and vice versa. It shows that electricity consumption is determined by economic growth. Any shock to the electricity supply will have effects on economic growth and vice versa.

For developed countries the error correction parameter is 0.894 and is positive and significant. There is a long-run relationship between the two variables. This parameter indicates the rate at 
which the short-run deviations resulting from the non-stationary series will impact on equilibrium in the next period. The results show that about $89 \%$ of imbalances in a period will be corrected in the next period. This will ensure a long-run equilibrium approach. Moreover, the long-run parameter of gross domestic product is 0.038 and is statistically significant; the short-run parameter is -0.036 and is statistically significant and negative. A $1 \%$ increase in gross domestic product in the short-run will result in a $0.03 \%$ decrease in electricity consumption.

For developing countries, the error correction parameter is 0.552 , positive and significant. This parameter indicates the rate at which the short-run deviations resulting from the non-stationary series will impact on equilibrium in the next period. The results show that about $55 \%$ of imbalances in a period will be corrected in the next period. This will ensure a long-run equilibrium approach. Moreover, the long-run parameter of gross domestic product is -0.34 and is statistically significant and negative, and the short-run parameter is 0.091 and is statistically significant and positive. A $1 \%$ increase in gross domestic production in the short-run will result in a $1 \%$ increase in electricity consumption.

For under-developed countries, the error correction parameter is 0.614 , which is positive and significant. This parameter indicates the rate at which the short-run deviations resulting from the non-stationary series will impact on equilibrium in the next period. The results show that about $61 \%$ of imbalances in a period will be corrected in the next period. This will ensure a long-run equilibrium approach. Moreover, the long-run parameter of gross domestic product is 0.156 , and the short-run parameter is 0.24 are both statistically significant and positive. A $1 \%$ increase in gross domestic product in the short run will result in a $2 \%$ increase in electricity consumption.

\section{CONCLUSIONS}

Electricity consumption depends on many factors, such as income levels of countries, technological developments, literacy status of people, and conscious usage of energy resources habits.

In this study we used the panel data of electricity consumption and GDP for 30 countries, using annual data from 1995 to 2014 . The countries studied were divided into three groups: developing, developed and under-developed countries. The aim of this study was to investigate whether there is a relationship between electricity consumption and per capita GDP; to examine the causality between these variables and to determine the significance of this relationship. The relationship between electricity consumption and GDP was determined by employing Pedroni (1999) panel cointegration method. The empirical results of the panel cointegration test indicated that electricity consumption and GDP are cointegrated for all three groups. Also, panel causality test results revealed that there is a long-run Granger causality running from GDP to EC for the three groups and vice versa. The results obtained are consistent with the findings of other researches $[10,12]$.

The overall results of this study show that there is a relationship between EC and GDP. In the short-run, this relationship is negative for developed countries but positive for developing and under-developed countries. In the long-run, this relationship is negative for developing 
countries but positive for developed and under-developed countries. This clearly indicates that electricity consumption differs according to the developmental level of the countries.

The short-term relationship in developed countries is negative. This is due to the continued increase in GDP despite the stagnation of electricity consumption. In terms of technology and industrialization, these countries are thought to have attained sufficient saturation.

In the developing countries, the long-term relationship has been observed to be negative. This shows that developing countries will reach fullness in terms of technology and industrialization in the long run.

For under-developed countries, technology and industrialization are not expected to reach saturation in the near future.

\section{REFERENCES}

[1] Kaygusuz, K. (2003). Energy policy and climate change in Turkey. Energy Conversion and Management, 44(10): 1671-1688.

[2] Suganthi, L. And Samuel, A. A. (2012). Energy models for demand forecasting- a review, Renewable Sustain Energy Rev, 16(2): 1223-1240.

[3] U.S. Energy Information Administration EIA, https://www.eia.gov/outlooks/ieo/pdf/0484(2017).pdf (accessed December 11, 2017).

[4] Bah, M. and Azam, M. (2017). Investigating the relationship between electricity consumption and economic growth: evidence from South Africa, Renewable and Sustainable Energy Reviews, 80: 531-537.

[5] Shahbaz, M. and Lean H., H. (2012). The dynamics of electricity consumption and economic growth: A revisit study of their causality in Pakistan, Energy, 39(1): 146-153.

[6] Odhiambo, N. M. (2009). Electricity consumption and economic growth in South Africa: a trivariate causality test, Energy Economics, 31(5): 635-640.

[7] Yuan, J. H., Kang, J., G., Zhao, C., H. and Hu, Z. G. (2008). Energy consumption and economic growth: evidence from China at both aggregated and disaggregated levels, Energy Economics, 30(6): 3077-3094.

[8] Aqeel, A. and Butt, M. S. (2001). The relationship between energy consumption and economic growth in Pakistan, Asia-Pacific Development Journal, 8(2): 101-110.

[9] Fotis, P., Karkalakos, S. and Asteriou, D. (2017). The relationship between energy demand and real GDP growth rate: the role of price asymmetries and spatial externalities within 34 countries across the globe, Energy Economics, 66: 69-84.

[10] Ozturk, I., Aslan, A. and Kalyoncu, H. (2010). Energy consumption and economic growth relationship: Evidence from panel data for low and middle income countries, Energy Policy, 38(8): 4422-4428.

[11] Wolde-Rufael, Y. (2006). Electricity consumption and economic growth: a time series experience for 17 African countries, Energy Policy, 34(10): 1106-1114.

[12] Soytas, U. and Sari, R. (2003). Energy consumption and GDP: causality relationship in G-7 countries and emerging markets, Energy Economics, 25(1): 33-37. 
[13] Bozoklu, S. and Y1lanc1, V. (2013). Energy consumption and economic growth for selected OECD countries: further evidence from the granger causality test in the frequency domain, Energy Policy, 63: 877-881.

[14] EC, Electricity Consumption. https://data.worldbank.org/indicator/EG.USE.ELEC.KH.PC (accessed April 20, 2018)

[15] GDP, Gross Domestic Product. https://data.worldbank.org/indicator/NY.GDP.PCAP.CD (accessed April 20, 2018).

[16] WDI, World Development Indicators. https://data.worldbank.org/products/wdi (accessed April 20, 2018).

[17] Levin, A., Lin, C., F. and Chu, C. S. J. (2002). Unit root tests in panel data: Asymptotic and finite-sample properties, Journal of Econometrics, 108(1): 1-24.

[18] Im, K.S., Pesaran, M., H. and Shin, Y. (2003). Testing for unit roots in heterogeneous panels, Journal of Econometrics, 115(1): 53-74.

[19] Hadri, K. (2000). Testing for stationarity in heterogeneous panel data, The Econometrics Journal, 3(2): 148161.

[20] Pedroni, P. (1999). Critical values for cointegration tests in heterogeneous panels with multiple regressors, Oxford Bulletin of Economics and Statistics, 61(1): 653-670.

[21] Granger, C.W.J. 1969. Investigating causal relations by econometric models and cross spectral methods, Econometrica, 37: 424-438.

[22] Lay, E., Chye, X.-H. and Choong, C.H.-K. 2011. Energy-growth causality: a panel analysis, International Conference on Applied Economics e ICOAE 2011.

[23] Engle, R.F. and Granger, C.W.J. 1987. Cointegration and error correction: representation, estimation, and testing, Econometrica, 55: 251-276. 